\title{
THE ASSOCIATION BETWEEN ASYMPTOMATIC BACTERIURIA AND GLYCEMIC CONTROL IN TYPE 2
}

\author{
Reni Marlina $^{1}$, Ricke Loesnihari ${ }^{1}$, Santi Syafril ${ }^{2}$ \\ ${ }^{1}$ Department of Clinical Pathology, School of Medicine, University of North Sumatera/Adam Malik Central Hospital Medan, Indonesia. E-mail: \\ renimarlina81@gmail.com; ${ }^{2}$ Department of Internal Medicine, School of Medicine, University of North Sumatera /Adam Malik Central Hospital \\ Medan, Indonesia
}

\begin{abstract}
The incidence of infection often occurs in patients with Diabetes Mellitus (DM) due to hyperglycemia that causes dysfunction of chemotaxis, phagocytic activity, malfunction of neutrophils and glycosuria. It is followed by other complications that lead to the malfunction of the bladder. Highly urinary glucose level is an exellent medium for pathogenic microorganisms growth. Asymptomatic Bacteriuria (ASB) is a risk factor for symptomatic urinary tract infection spontaneously or due to urinary catheters. This study aimed to analyze the association between the incidence of ASB of type 2 DM and glycemic control. The study was conducted during June-August 2016 with a cross-sectional method. Subjects were type 2 DM patients with age $\leq 60$ years, who were treated in the Endocrinology Out-Patient Clinic of the Adam Malik Hospital. HbA1c was measured by Indiko automatic analyzer. Its association with urine culture results was analyzed. A total of 50 samples were enrolled, consisting of 25 females, and 25 males, with 19 having an exellent glycemic control (HbA1c <7\%) and 31 with poor glycemic control (HbA1c $\geq 7 \%)$. Thirteen positive ASB were found, 5 with good glycemic control and 8 with poor glycemic control. Statistical analysis revealed a nonsignificant association between glycemic control and culture results $(p=1.000)$. Somers' $d$ did not show a significant association between glycemic control and the incidence of ASB $(p=0.968, d=-0.005)$. However, significant differences in culture results between gender, in which the ASB were found in samples of four females and two males $(p=0.004)$. Somers' $d$ revealed a significant association between culture results and gender $(p=0.001 ; d=-0.360)$. Most of the bacteria found were Gram-negative. There was no significant association between glycemic control with an incidence of ASB. However, gender had significant differences in the incidence of ASB, which occurred more frequently in DM females than males. Urinalysis should be performed in patients with type $2 \mathrm{DM}$ with ASB. However, further study was needed to analyze the relationship between glycemic control with the incidence of ASB and other factors that might affect the incidence of ASB.
\end{abstract}

Key words: Asymptomatic bacteriuria, type 2 diabetes mellitus, $\mathrm{HbA1c}$

\section{INTRODUCTION}

Diabetes Mellitus (DM) is a group of metabolic diseases with hyperglycemic characteristics that happened due to insulin secretion disorders, the way insulin works or both. ${ }^{1}$ Diabetes mellitus epidemiology threatens the health of a lot of people, both in advanced and in developing countries. ${ }^{2}$ The International Diabetes Federation (IDF) predicts an increase in DM patients in Indonesia from 9,1 million in 2014 to 14,1 million in 2035, which at that point Indonesia will have the $7^{\text {th }}$ highest total of DM patients in the world. ${ }^{3}$

Diabetes Mellitus patients with high blood glucose concentrations, easily get infected by various systemic infections, 4.4 times more than patients without DM. ${ }^{4}$ Infections in DM are the most severe complications that have become world health problems. ${ }^{5}$ Infections happen more in patients with DM due to the hyperglycemic environment that increases the pathogenic virulence, decreases interleukin production, causing chemotaxis and phagocytic activity dysfunction, damaged neutrophil function, glycosuria and gastrointestinal, and urinary tract dysmotility. These conditions can also be accompanied by other complications that are related to neuropathy causing malfunctions of the bladder that can cause the higher risk of infection, especially Urinary Tract Infections (UTI), ${ }^{3,6,7}$

Glycemic control is based on glycated hemoglobin (HbA1c) examinations. HbA1c is the gold standard to control a patients blood glucose concentration. Diabetes mellitus is stated as under good control if the levels of $\mathrm{HbAlc}<7 \%$ and $\mathrm{DM}$ is unregulated the $\mathrm{HbAlc} \geq 7 \%$. HbAlc is now used as an indicator and marker that is significant for glucose control describing the mean plasma glucose from $6-8$ weeks before. ${ }^{1,8}$ Bad glycemic control may cause kidney injury, and is a predisposition of UTI. ${ }^{9}$

Asymptomatic bacteriuria is a risk factor for symptomatic UT and can cause a decrease in renal function, which needs serious handling..$^{10}$ Asymptomatic Bacteriuria (ASB) is bacterial colonization persistent in the urinary tract without clinical symptoms, that shows pure microorganism growth more that $10^{\wedge} 5$ Colony Forming Units (CFU/mL) in urine culture in every milliliter of fresh urine taken from midstream. ${ }^{11,12}$ 
High glucose levels in urine are an exellent growth media for pathogenic microorganisms. ${ }^{13,14}$ Infection in DM patients is influenced by blood glucose control and high blood glucose concentration can increase vulnerability or aggravate the infection.

The purpose of the experiment was to determine, whether there was a correlation in asymptomatic bacteriuria in DM type 2 patients with glycemic control and learn the difference of asymptomatic bacteriuria in DM type 2 with regulated and unregulated $\mathrm{HbAlc}$ concentrations.

\section{METHODS}

This experiment was held during June - August 2016 by observational, analytical cross-sectional method at the UP HAM. HbAlc was measured by an automatic Thermo Fisher Scientific Indiko Analyzer with a turbidimetric inhibition immunoassay and correlated it with urine culture result. Urine was taken by midstream clean catch, using CLED Agar (Cystine Lactose Electrolyte Deficient) media. Inclusion criteria were DM type 2 patients who underwent therapy at the Endocrinology Out-Patient Clinic of the Adam Malik Hospital Medan, with no symptoms of UTI (fever, urgency, frequency, dysuria), age $\leq 60$ years old. The exclusion criteria were DM patients with the urine catheter, DM patients with UT that already received antibiotic therapy, anemia, pregnant patients, hemoglobinopathy and chronic kidney disease.

Statistical Analysis was done with Statistical package for social science (SPSS) Version 20 software. The variables of this experiment were shown in tabulation and were described. To observe the difference between asymptomatic bacteriuria in controlled $\mathrm{HbAlc}$ and uncontrolled $\mathrm{HbAlc}, \mathrm{X}^{2}$ (chi-square) test was used, unless there is an expected count $<5$, whereas the Exact Fisher test was be used. To observe was the relationship between asymptomatic bacteriuria with glycemic control the Somers' $d$ association was used.

\section{RESULTS AND DISCUSSION}

This experiment was done by an analytically observational cross-sectional method. This experiment was done from June August 2016, 50 samples of DM type 2 patients were obtained that fulfilled the inclusion, and exclusion criteria. Subject' $s$ charateristic, can be seen in Table 1, where there were 25 females and 25 males with a mean of $54.16 \pm 3.919$ years old, $\mathrm{HbAlc}$ median $7.2 \%$ with a range of $5.3-15.1 \%$.

As shown in Table 2, ASB was found in 11 female patients (44\% of the total of female patients) and two male patients ( $8 \%$ of the total of male patients). The results of the $x^{2}$ test showed a significance from the sex variable towards ASB $(p=0.004)$. Somers' $d$ association from sex and culture results were very significant but low and negative. $(p=0.001 ; d=-0.360)$.
Table 1. Characteristics of experiment subjects

\begin{tabular}{lc}
\multicolumn{2}{l}{ Table 1. Characteristics of experiment subjects } \\
\hline Characteristics & Total \\
\hline $\mathrm{n}$ (people) & 50 \\
Age (years old) & 54.16 \\
Mean & $(3.919)$ \\
(SD) & \\
HbA1c & \\
Median & 7.2 \\
(min-max) & $(5.3-15.1)$ \\
Sex & \\
$\quad$ Female & 25 \\
$\quad$ Male & 25 \\
\hline
\end{tabular}

Table 2. Cross-tabulation of sex and ASB incidence

\begin{tabular}{lcccc}
\hline & Total & \multicolumn{2}{c}{ ASB incidence } & \\
\cline { 3 - 4 } & & $\begin{array}{c}\text { Negative } \\
(-)\end{array}$ & $\begin{array}{c}\text { Positive } \\
(+)\end{array}$ & P-value \\
\hline $\mathrm{n}$ (people) & 50 & 37 & 13 & $0.004^{\star}$ \\
Sex & & & & \\
Female & 25 & 14 & 11 & $0.001^{\wedge}$ \\
Male & 25 & 23 & 2 & \\
\hline
\end{tabular}

$\wedge$ = Somers $\mathrm{d}^{\prime}$ association tes

${ }^{*}=X^{2}$ test (chi-square)

The results were significant when $p<0.05$.

In Table 3, there were 19 patients with controlled $\mathrm{HbAlc}(<7 \%)$ and 31 patients with uncontrolled $\mathrm{HbA1c}(62 \%)$. Urine culture results showed that ASB was found in 5 patients with controlled $\mathrm{HbAlc}$ and 8 patients with uncontrolled HbAlc. According to the Exact Fisher examination, there was no significant ASB between controlled and uncontrolled DM type $2(p=1.000)$.

As shown in Table 4 the calculation of association of Somers' $d$, also did not show any significant relationship or association between glycemic control and ASB ( $p=$ 0.968; $d=-0.0005$ ).

For female patients with DM type 2, 13 patients (52\%) were found with controlled $\mathrm{HbAlc}(<7 \%)$ and 12 patients (48\%) with uncontrolled HbAlc (> 7\%). As shown in Table 5, urine culture showed ASB in 4 female patients with controlled HbA1c DM type 2 and seven patients with uncontrolled HbA1c DM type 2.

The $\times 2$ test results showed that there was no significant difference between ASB in female patients with controlled, and uncontrolled DM type 2 ( $p=0.165)$. Somers' $d$ association calculation also did not show any significant difference between glycemic control and female patient DM type 2 with ASB $(p=0.150$; $d=0.276)$.

Urine culture results as shown in Table 6 showed that the bacteria most found were Gram-negative bacteria (10 from 13 samples with significant bacteria growth were found). E.coli was found in 4 samples, Enterococus cloacae, Klebsiella Pneumonia and Acinetobacter baumannii, .

Table 3. The difference of ASB between controlled and uncontrolled DM type 2

\begin{tabular}{lcc}
\hline & & \\
& & ASB \\
\cline { 2 - 3 } & Negative (-) & Positive (+) \\
\hline Glycemic control (HbA1C) & & 5 \\
$<7 \%$ & 14 & 8 \\
$\geq 7 \%$ & 23 & 13 \\
Total & 37 & $1.000^{*}$ \\
\hline *Fisher Exact Test & & \\
\hline
\end{tabular}

*Fisher Exact Test 
Table 4. Association between glycemic control with ASB

\begin{tabular}{lcc}
\hline & \multicolumn{2}{c}{ ASB } \\
\cline { 2 - 3 } & P-value & Somers' d association quotient \\
& & (d) \\
\hline $\begin{array}{l}\text { Glycemic } \\
\text { control }\end{array}$ & $0.968^{*}$ & -0.005 \\
\hline *Somers' d association test &
\end{tabular}

Enterococus faecalis were found in two samples each, last of all, Streptococus pyogenes was found in one sample

The experiment was done with an analytical observational cross-sectional method to see the relationship between ASB, and glycemic control in DM type 2 patients. Samples were 25 female and 25 male patients with a mean age of 54.16 (3.919) years old. The median of HbAlc $7.2 \%$ was with a range of $5.3-15.1 \%$.

Urine culture results found ASB samples in 13 people (26\% of the total samples) consisting of 11 female patients ( $44 \%$ of the total of female patients) and 2 male patients ( $8 \%$ of the total of male patients). These results were consistent with the previous experiments in various countries where the prevalence of ASB in DM patients varied from $5.8-53 \%{ }^{15,16}$

The $x^{2}$ test showed the significant difference from sex variables towards BAS $(p=0.004)$. The Somers' $d$ association between sex and culture results were significant but weak and negative $(p=0.001, d=-0.360)$. These results were not different from previous experiments where the prevalence of ASB in female DM patients was 9-29\%, and higher than male DM $(0.7-11 \%) .{ }^{17}$

Table 5. Difference between ASB and female patients with controll0ed, and uncontrolled DM type 2

\begin{tabular}{lccc}
\hline & \multicolumn{2}{c}{ ASB } & \\
\cline { 2 - 3 } & $\begin{array}{c}\text { Negative } \\
(-)\end{array}$ & $\begin{array}{c}\text { Positive } \\
(+)\end{array}$ & P-value \\
\hline Glycemic control (HbA1c) & & & \\
$<7 \%$ & 9 & 4 & $0.165^{\star}$ \\
$\geq 7 \%$ & 5 & 7 & $0.276^{\wedge}$ \\
& 14 & 11 & \\
\hline Total & 14 &
\end{tabular}

${ }^{*}$ X2 test (chi-square)

$\wedge$ Somers' d association

Tests were significant if $p$ was $<0.05$

This happened because the anatomical distance between the colon from the female urethra is closer than the male and the female urethra is shorter. Other than that, the urethra' $s$ orifice with the vagina is a space that is easier to become bacterial colonization. Infection that comes from bacterial pathogen in the gut flora, spreads from the perineal vaginal and periurethral to the bottom of the urinary tract to form a colony. There were 19 patients (38\%) with controlled $\mathrm{HbA1c}$ $(<7 \%)$ and 31 patients $(62 \%)$ with uncontrolled HbA1c. There were 13 female patients with $\mathrm{HbA} 1 \mathrm{c}<7 \%$, and DM type 2 and 12 patients with $\mathrm{HbAlc} \geq 7 \%$, and 6 male with $\mathrm{HbAlc}<$ $7 \%$ DM type 2 and 19 with $\geq 7 \%$.

Urine culture results showed 5 patients with ASB and controlled $\mathrm{HbAlc}$ and eight patients with uncontrolled
Table 6. Bacteria of urine culture result

\begin{tabular}{cc}
\hline Types of bacteria & Total \\
\hline Gram-negative bacteria & $\mathbf{1 0}$ \\
Escherichia coli & 4 \\
Enterobacter cloacae & 2 \\
Klebsiella pneumonia & 2 \\
Acinetobacter baumannii & 2 \\
Gram-positive bacteria & $\mathbf{3}$ \\
Enterococcus faecalis & 2 \\
Streptococcus pyogenes & 1 \\
Total & $\mathbf{1 3}$
\end{tabular}

$\mathrm{HbA1c}$. The Fisher test showed that there was no difference between ASB in controlled and uncontrolled DM type 2 $(p=1.000)$. The Somers' $d$ association calculation did not find any significant association between glycemic control with ASB happenings ( $p=0.968 ; d=-0.005)$.

These experiment results were the same as the previous experiments by Boroumand.7 Boroumand et al. examinations on Iran females with DM type 2 showed no significant relationship or correlation between $\mathrm{HbA1c}$ with $\mathrm{ASB}(\mathrm{p}=0.75) .7$

E.coli was the most often organism found in patients with ASB. There were many organisms infecting the urinary tract, including Enterobacteriaceae (including Proteus, Klebsiella, Enterobacter, and Citrobacter species), Pseudomonas aeruginosa, Enterococcus species, Gardnerella vaginalis, streptococci, staphylococci, Candida albicans, and other fungi.

In this experiment, E.coli was found in 4 of 13 samples that had significant bacteria growth. Enterococcus cloacae, Klebsiella pneumoniae and Acinetobacter baumannii, with Gram-negative bacteria and Enterococcus faecalis as a Gram-positive that were found in every 2 samples.

Results from this experiment were consistent with experimental results by Turan et al. Viswanath et al. and Boroumand et al. ${ }^{17-18}$ In these experiments the bacteria that caused ASB were usually from enteric colonies like E.coli and Enterobacter sp. In a couple other experiments, Klebsiella was reported as the most likely bacteria to cause ASB.16 In this experiment, the bacteria found to be the most likely cause of ASB were Gram-negative bacteria, with the highest percentage of E.coli the normal flora of the gut.

The capability of E.coli to infect the urinary tract is due to the pili or fimbriae that specifically becomes a mediator (adhesion) between urinary tract epithelial cells. Uropathogenic bacteria can reach the tissues of the urinary tract and adhere to the epithelial and start to colonize, by excreting toxins that cause an inflammatory reaction in that location and eventually the whole body. ${ }^{18}$

\section{CONCLUSION AND SUGGESTION}

There was no significant relationship between glycemic control with ASB happenings in DM type 2 patients. There were significant differences due to sex towards $A S B$, where ASB was found more in female patients with DM type 2 than male patients with DM type 2 . The bacterial pattern from 
this experiment was $76.9 \%$ Gram-negative bacteria and 9 . 23.1\% Gram-positive bacteria.

Urinalysis screening must be done in DM type 2 patients with ASB. Further experiments are needed to analyze the relationship between glycemic control with ASB and other factors that can influence $A S B$, so ASB in DM type 2 patients can be prevented.

\section{REFERENCES}

1. Saptiningsih $M$. determinan infeksi saluran kemih pasien DM perempuan di RSB Bandung. Bandung, FKUI, 2012; 2 .

2. American Diabetes Association. Position statement: Standards of medical care in diabetes. Diabetes Care. 2015; 38(1): S11.

3. Perkumpulan Endokrinologi Indonesia. Konsensus pengendalian dan pencegahan diabetes mellitus tipe 2 di Indonesia. Jakarta, PB. PERKENI, 2015; 1.

4. Burekovic A, Amela DB, Amina G. Poorly regulated blood glucose in diabetic patients-predictor of acute infection. Med Arh. 2014; 68 (3): 163-6.

5. Douri FE. Prevalence of silent bacteriuria in patients with diabetes mellitus. Department of medical microbiology Baghdad. The Iraq Postgraduate Medical Journal. 2008; 7(1): 60.

6. Sunnesh AR, Kale D, Venkat K, Rameswar RM, Kandati J, Pasupuleti 16. $\mathrm{SR}$. Prevalence of asymptomatic bacteriuria and its antibiotic sensitivity in type-2 diabetic women along the sea coast. Int J Res Med Sci. 2013; 1(4): 487-95.

7. Boroumand MA, Sam L, Abbasi S. Asymptomatic bacteriuria in type 17 . 2 Iranian diabetic women: A cross-sectional study. BMC Women's Health. 2006; 6(4): 1.

8. Singhal $\mathrm{S}$, Dandu $\mathrm{H}$, Arvid KV. A study of asymptomatic bacteriuria in north indian type 2 diabetic patients. J Diabetes Metab. 2015; 618 (11): 2 .
Abdul IO, Osazuwa F, Osilume D. Association between elevated HbA1c levels and Urinary Tract Infection among Diabetic Women. Zahedan University of Medical Sciences. Zahedan J Res Med Sci. 2015; 17(6): e994.

10. Chourasia MK. Asymptomatic pyuria is a growing yet an ignored concern: An exploratory study from rural India. J Community Med Health Educ. 2014; 4(5): 321

11. Boekitwetan P. Komplikasi bakteriuria pada kehamilan. Bagian Mikrobiologi FK Universitas Trisakti. J Kedokter Trisakti. 2000; 9 (3): 91.

12. Sukandar E. Infeksi saluran kemih pasien dewasa. In: Buku ajar ilmu penyakit dalam, Setiawati S, Alwi I, Sudoyo AW, Simadibrata M, Setiyohadi B, Syam AF(eds.). Jakarta, Interna Publishing, 2014; 2129.

13. Sharma BD, Bansal R, Gupta B. Asymptomatic bacteriuria in diabetes. JIACM. 2011; 13(1): 55-9.

Samuel OO, Akinleye OM, Deji AAM, Olaniyan JAT, Akintunde BG, Buhari OA. Asymptomatic urinary tract infection in diabetic patients in Ago-Iwoye. Journal of American Science. 2014; 10(4s): 72-7.

15. Deraje A, Shenoy S, Dhanshree B, Prabha A. Asymptomatic bacteriuria with E.coli in type 2 diabetic patients: An unresolved riddle. British Journal of Medicine \& Medical Research. 2016; 11 (3): 1-9.

Turan H, Serefhanoglu K, Torun AN. Frequency, risk factors and responsible pathogenic microorganism of asymptomatic bacteriuria in patients with type 2 diabetes mellitus. JPN. J. Infect. Dis. 2008; 61(3): 236-8.

Vishwanath S, Radhika S, Annet OD, Chiranjay M. Asymtomatic bacteriuria among patients with diabetes mellitus at a tertiary care center. National Journal of Laboratory Medicine. 2013; 2(3) 16-19.

Ariwijaya M, Suwitra K. Prevalensi, karakteristik dan faktor-faktor yang terkait dengan infeksi saluran kemih pada penderita diabetes melitus yang rawat inap. Jurnal Penyakit Dalam. 2007; 8 (2): 112-27. 